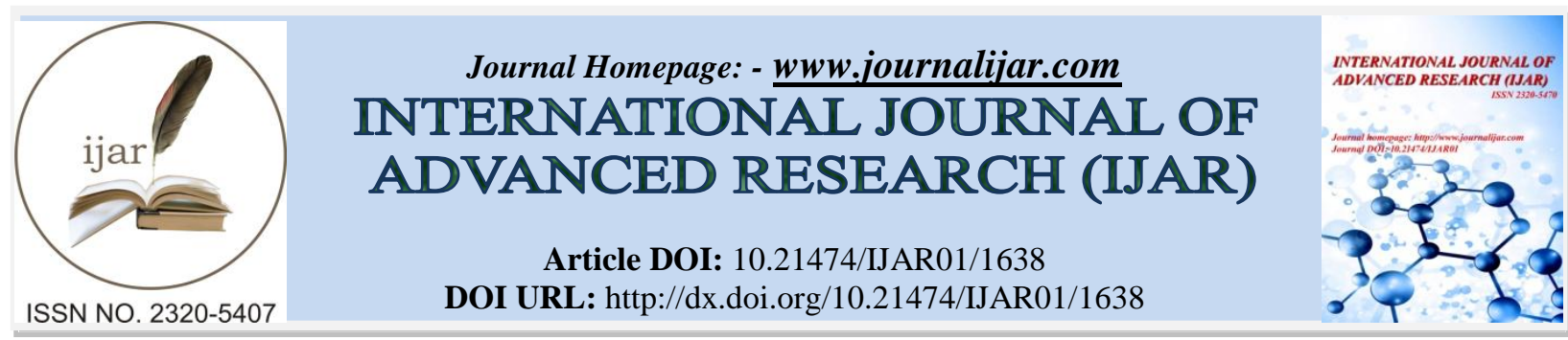

RESEARCH ARTICLE

\title{
A CORRELATIVE STUDY OF SERUM INORGANIC PHOSPHATE CONCENTRATION AND FASTING BLOOD GLUCOSE IN TYPE 2 DIABETES MELLITUS - A HOSPITAL BASED STUDY.
}

Dr. Girindra Kr. Bora ${ }^{1}$, Dr. Rashmi Rajkakati ${ }^{2}$ and Dr Sushma Yadav ${ }^{1}$.

1. Demonstrator, Department of Biochemistry, Jorhat Medical College, Jorhat-785001, Assam, India.

2. Associate professor. Department of Biochemistry, Assam Medical College, Dibrugarh-786002, Assam, India.

\section{Manuscript Info}

Manuscript History

Received: 12 July 2016

Final Accepted: 13 August 2016

Published: September 2016

Key words:-

Diabetes, inorganic phosphate, fasting blood glucose.

\section{Abstract}

\section{Objective:}

1. To study serum inorganic phosphate concentration and fasting blood glucose in patients with type 2 diabetes mellitus.

2. To find the correlation between serum inorganic phosphate level and fasting blood glucose in patients with type 2 diabetes mellitus.

Materials and methods:- The study was carried out on 50 newly diagnosed patients of type 2 diabetes and controls in the Department of Biochemistry, Assam medical college, Dibrugarh. Analysis of blood glucose (fasting and postprandial), serum inorganic phosphate, urea and creatinine concentrations were performed by standard methods using semi automated analyser.

Results:- Concentrations of fasting and postprandial blood glucose higher in the diabetic group than controls $(\mathrm{p}<0.01)$. The mean serum inorganic phosphate concentration in cases was found to be significantly lower than controls $(2.68 \pm 0.56 \mathrm{vs} 3.64 \pm 0.42 \mathrm{mg} / \mathrm{dl})$ and $\mathrm{p}<0.01$. Present study revealed an inverse relationship between serum inorganic phosphate concentration and fasting blood glucose in patients with type 2 Diabetes Mellitus with a correlation coefficient, $r$ $=-0.67$ substantiated by regression analysis.

Conclusion:- There is definite reduction of serum inorganic phosphate concentration in type 2 Diabetes Mellitus patients and that reduction of serum inorganic phosphate concentration may have a contributing role in the progression of the disease and development of complications of diabetes.

Copy Right, IJAR, 2016,. All rights reserved.

\section{Introduction:-}

Diabetes mellitus is a group of metabolic disorders of carbohydrate metabolism in which glucose is underused, producing hyperglycemia ${ }^{1}$. There are two main forms of diabetes. Type 1 diabetes is due primarily to autoimmunemediated destruction of pancreatic b-cell islets, resulting in absolute insulin deficiency. Its frequency is low relative to type 2 diabetes, which accounts for over $90 \%$ of cases globally. Type 2 diabetes is characterized by insulin resistance and/or abnormal insulin secretion, either of which may predominate ${ }^{2}$. 
Diabetes is an "iceberg" disease. Although increase in the prevalence and incidence of type 2 diabetes have occurred globally, they have been especially dramatic in societies in economic transition, in newly industrialized countries and in developing countries. Currently the number of cases of diabetes worldwide is estimated to be around 347 million; of these more than 90 percent are type 2 diabetes $^{3}$.

Diabetes is a major cause of mortality, but several studies indicate that diabetes is likely underreported as a cause of death. A recent estimate suggested that diabetes was the fifth leading cause of death worldwide and was responsible for almost 4 million deaths in 2010 (6.8\% of deaths were attributed to diabetes worldwide $)^{4}$.

Type 2 diabetes is a global public health crisis that threatens the economies of all nations, particularly developing countries. Fueled by rapid urbanization, nutrition transition, and increasingly sedentary lifestyles, the epidemic has grown in parallel with the worldwide rise in obesity. Asia's large population and rapid economic development have made it an epicenter of the epidemic ${ }^{5}$.

The recently published ICMR-INDIAB national study reported that there are 62.4 million people with type 2 diabetes (T2DM) and 77 million people with pre-diabetes in India. These numbers are projected to increase to 101 million by the year 2030. The complications related to diabetes pose a significant health care burden and a deterrent to overall quality of life. The Chennai Urban Population Study (CUPS) and Chennai Urban Rural Epidemiology Study (CURES) are one of the few population based studies on complications of diabetes in India and show that there is a huge burden due to diabetes related complications in India. The prevalence of diabetic retinopathy (DR) was $17.6 \%$, microalbuminuria was $26.9 \%$, neuropathy was $26.1 \%$, coronary artery disease (CAD) was $21.4 \%$ and peripheral vascular disease (PVD) was $6.3 \%$. The cost of treatment for diabetic complications adds to the health care costs. India thus faces a huge health care burden due to high prevalence of type 2 diabetes and its complications ${ }^{6}$.

An adult has about $600 \mathrm{~g}$ or approximately $20 \mathrm{~mol}$ of phosphorus as inorganic and organic phosphates, of which about $85 \%$ is in the skeleton, and the rest is principally in soft tissue. Plasma contains both inorganic and organic phosphate, but only inorganic phosphate is measured. Inorganic phosphate is a major component of hydroxyapatite in bone; thus it plays an important role in the structural support of the body and provides phosphate for the extracellular and intracellular pool?

Early in the progression of diabetes, a paradoxical metabolic imbalance in inorganic phosphate (Pi) occurs that may lead to reduced high energy phosphate and tissue hypoxia. These changes take place in the cells and tissues in which the entry of glucose is not controlled by insulin, particularly in poorly regulated diabetes patients in whom long-term vascular complications are more likely. Various conditions are involved in this disturbance in Pi. First, the homeostatic function of the kidneys is suboptimal in diabetes, because elevated blood glucose concentrations depolarize the brush border membrane for Pi reabsorption and lead to lack of intracellular phosphate and hyperphosphaturia. Second, during hyperglycemic-hyperinsulinemic intervals, high amounts of glucose enter muscle and fat tissues, which are insulin sensitive. Intracellular glucose is metabolized by phosphorylation, which leads to a reduction in plasma $\mathrm{Pi}$, and subsequent deleterious effects on glucose metabolism in insulin insensitive tissues. While low and high uncontrolled blood sugars give rise to easily recognizable clinical symptoms, low and high plasma inorganic phosphate remains unrecognizable or presents vague and general symptoms. Hypophosphatemia is strongly related to a decrease in intracellular adenosine triphosphate (ATP) in the aging process and in uremia. Any interruption of optimal ATP production might lead to cell injury and possible cell death ${ }^{8}$.

In this background, it has become necessary to study the status of serum inorganic phosphate in type 2 diabetes mellitus and its association with fasting blood glucose in this region where no such study has been undertaken before. Therefore a humble effort is made to undertake this study with the following aims and objectives.

\section{Material and methods:-}

The present study "A correlative study of Serum Inorganic Phosphate concentration and fasting blood glucose in type 2 Diabetes Mellitus - A hospital based study." is a hospital based study carried out on newly diagnosed cases of type 2 diabetes mellitus who attended and/or was admitted in the Department of Medicine, Assam Medical College and Hospital. The study was conducted in the Department of Biochemistry and Advanced Clinical Biochemistry Laboratory, Assam Medical College and Hospital, Dibrugarh. 
Place of study:- Department of Biochemistry, Advanced Clinical Biochemistry Laboratory, Assam Medical College and Hospital.

Duration of study:

No of cases :

No of controls :

Type of study :

Selection of cases:

August' 2013 to September' 2014

50 (fifty)

50 (fifty)

Case-Control Study.

Patients were selected randomly on a weekly basis.

\section{Inclusion criteria:-}

Newly diagnosed cases of type 2 diabetes mellitus who attended and/or was admitted in Department of Medicine, Assam Medical College and Hospital.

Patients were selected on the basis of clinical history, clinical examination and relevant clinical investigations. The individuals were selected irrespective of sex and socio-economic status.

Sex- Male and Female.

Controls- age and sex matched healthy subjects.

\section{Exclusion criteria:-}

Patients with diagnosed type 1 diabetes mellitus.

Patients who did not give consent to the study.

Pregnant women.

Patients receiving Phosphate supplementation.

Patients with Chronic Renal Diseases.

Patients on drugs that alter serum phosphate level or drugs modifying metabolism of phosphate.

Patients with hepatic disorders, renal disorders, malignancies, myocardial infarction, patients on diuretics, bleeding disorders and other major illness.

Smokers and Alcoholics.

\section{Criteria for diagnosis of diabetes mellitus:-}

Patients will be considered diabetic according to the criteria defined by American Diabetes Association 2011 criteria ${ }^{9}$.

For all parameters, a semi-autoanalyzer( MERCK Microlab 300) was used.

Required reagents were used for estimation of parameters.

\section{Test procedures:-}

Serum inorganic phosphate (molybdate u .v. method)

Fasting blood glucose, postprandial blood glucose (GOD/POD Method)

\section{Statistical analysis:-}

Arithmetic mean and standard deviation were worked out to assess the levels of various parameters in both groups under study. Students 't' test was used for comparison of quantitative variables. Co-relation between serum inorganic phosphate and Fasting blood glucose in patients was evaluated using Pearson Co-relation Co-efficient. All tests were considered statistically significant if the p-value was <0.05. All statistical analysis were done in Microsoft Excel, Graphpad.

\section{Results:-}

Concentration of fasting, postprandial blood glucose was higher in cases than in controls $(p<0.01)$. The mean \pm SD of blood urea and serum creatinine was slightly higher in cases than control but statistically this difference was not significant $(\mathrm{p}>0.05)$. The mean serum inorganic phosphate concentration was found to be significantly lower in cases than controls $(2.68 \pm 0.56$ vs $3.64 \pm 0.42)$ and $p<0.01$. Present study revealed a negative relationship between serum inorganic phosphate concentration and Fasting blood glucose in patients with type 2 diabetes mellitus with a pearson correlation coefficient, $\mathrm{r}=-0.67$. 
Table 1:- Showing Range and Mean \pm SD of serum inorganic phosphate in study subjects.

\begin{tabular}{|c|c|c|c|c|c|}
\hline \multirow{3}{*}{$\begin{array}{l}\text { STUDY } \\
\text { GROUP }\end{array}$} & \multicolumn{4}{|c|}{ SERUM INORGANIC PHOSPHATE $\quad(\mathrm{mg} / \mathrm{dL})$} & \multirow{3}{*}{$\begin{array}{l}\text { SIGNIFICANCE } \\
p \text { value }\end{array}$} \\
\hline & \multicolumn{2}{|c|}{ MALE } & \multicolumn{2}{|c|}{ FEMALE } & \\
\hline & RANGE & $\mathrm{MEAN} \pm \mathrm{SD}$ & RANGE & MEAN \pm SD & \\
\hline CASES & $1.9-4.0$ & $2.73 \pm 0.58$ & $1.9-3.5$ & $2.6 \pm 0.54$ & $>0.05$ \\
\hline CONTROLS & $2.8-4.4$ & $3.64 \pm 0.46$ & $2.9-4.3$ & $3.63 \pm 0.36$ & $>0.05$ \\
\hline
\end{tabular}

It is observed from table 1 that the mean serum inorganic phosphate level in male cases had been $2.73 \pm 0.58 \mathrm{mg} / \mathrm{dL}$ and that in female cases $2.6 \pm .0 .54 \mathrm{mg} / \mathrm{dL}$. In the control group, the mean serum inorganic phosphate level in males had been $3.64 \pm 0.46 \mathrm{mg} / \mathrm{dL}$ and that in female, $3.63 \pm 0.36 \mathrm{mg} / \mathrm{dL}$. The difference between the mean serum inorganic phosphate level between males and females in cases and in controls was very minimal and it was statistically not significant $(\mathrm{p}>0.05)$.

Table 2:- Age-wise distribution of mean serum inorganic phosphate levels in study subjects.

\begin{tabular}{|l|l|l|l|l|l|}
\hline \multirow{2}{*}{$\begin{array}{l}\text { Age } \\
\text { Group }\end{array}$} & \multicolumn{3}{|l|}{ SERUM INORGANIC PHOSPHATE $(\mathrm{mg} / \mathrm{dL})$} & \multirow{2}{*}{ value } \\
\cline { 2 - 5 } & Case & Mean \pm SD & Rantrol & Mean \pm SD & \\
\cline { 2 - 5 } & Range & $2.35 \pm 0.48$ & $2.9-4.4$ & $3.36 \pm 0.46$ & $<0.01$ \\
\hline$<40$ & $1.9-3.1$ & $2.85 \pm 0.55$ & $3.1-4.3$ & $3.75 \pm 0.37$ & $<0.01$ \\
\hline $41-50$ & $2.0-4.0$ & $2.81 \pm 0.60$ & $2.8-4.3$ & $3.53 \pm 0.41$ & $<0.01$ \\
\hline $51-60$ & $2.0-3.7$ & $3.2-4.2$ & $3.77 \pm 0.35$ & $<0.01$ \\
\hline $61-70$ & $1.9-3.2$ & $2.51 \pm 0.51$ & $3.3-4.4$ & $3.85 \pm 0.53$ & $<0.01$ \\
\hline$>70$ & $2.0-2.9$ & $2.40 \pm 0.42$ & $2.8-4.4$ & $3.64 \pm 0.42$ & $<0.01$ \\
\hline Total & $1.9-4.0$ & $2.68 \pm 0.56$ & & & \\
\hline
\end{tabular}

Overall, the mean serum inorganic phosphate level in cases was $2.68 \pm 0.56 \mathrm{mg} / \mathrm{dL}$ and that in controls is $3.64 \pm 0.42$ $\mathrm{mg} / \mathrm{dL}$. It was observed that the serum inorganic phosphate level in cases was lower than that in controls and it was statistically highly significant $(\mathrm{p}<0.01)$.

Table 3:- Showing Mean \pm SD of fasting blood glucose and post prandial blood glucose in study subjects.

\begin{tabular}{|l|l|l|l|}
\hline $\begin{array}{l}\text { STUDY } \\
\text { GROUP }\end{array}$ & NUMBER & $\begin{array}{l}\text { FASTING BLOOD } \\
\text { GLUCOSE }(\mathrm{mg} / \mathrm{dL})\end{array}$ & $\begin{array}{l}\text { POST PRANDIAL BLOOD GLUCOSE } \\
(\mathrm{mg} / \mathrm{dL})\end{array}$ \\
\hline Cases & 50 & $187.72 \pm 54.20$ & $302.28 \pm 85.75$ \\
\hline Controls & 50 & $85.94 \pm 11.42$ & $122.62 \pm 9.35$ \\
\hline
\end{tabular}

It is observed from Table 3 that the mean concentration of fasting blood glucose and post prandial blood glucose in cases were significantly higher than in controls.

Table 4:- Showing Inorganic Phosphate levels (mean $\pm \mathrm{SD}$ ) against fasting blood glucose in cases.

\begin{tabular}{|l|l|l|}
\hline \multicolumn{1}{|c|}{ FBG $(\mathrm{mg} / \mathrm{dL})$} & No & Inorganic Phosphate (Mean \pm SD) \\
\hline$<200$ & 34 & $2.93 \pm 0.48$ \\
\hline$\geq 200$ & 16 & $2.14 \pm 0.25$ \\
\hline P- value & $<0.01$ \\
\hline
\end{tabular}

It is observed from the table 4 that $\mathrm{FBS} \geq 200 \mathrm{mg} / \mathrm{dL}$ group had lower phosphate $(2.14 \pm 0.25 \mathrm{mg} / \mathrm{dL})$ than the group which had FBS $<200 \mathrm{mg} / \mathrm{dL}$ and it was statistically highly significant $(\mathrm{p}<0.01)$.

Table 5:- showing the correlation between fasting blood glucose and serum inorganic phosphate levels in diabetic cases.

\begin{tabular}{|l|l|l|}
\hline Fasting blood glucose Range $(\mathrm{mg} / \mathrm{dL})$ & \multicolumn{2}{|l|}{ Serum Inorganic Phosphate } \\
\cline { 2 - 3 } & r-value & $\mathrm{p}$-value \\
\hline $128-337$ & $\mathbf{- 0 . 6 7}$ & $<0.01$ \\
\hline
\end{tabular}

It is seen from table 5 that serum inorganic phosphate levels showed a negative correlation with fasting blood glucose levels, that was statistically significant $(\mathrm{p}<0.01)$. The Pearson correlation coefficient " $\mathrm{r}$ " which was found to be $\mathbf{- 0 . 6 7}$ established the negative correlation between the two parameters. 
Fig 1:- Showing the correlation between fasting blood gucose and serum inorganic phosphate levels in diabetic cases.

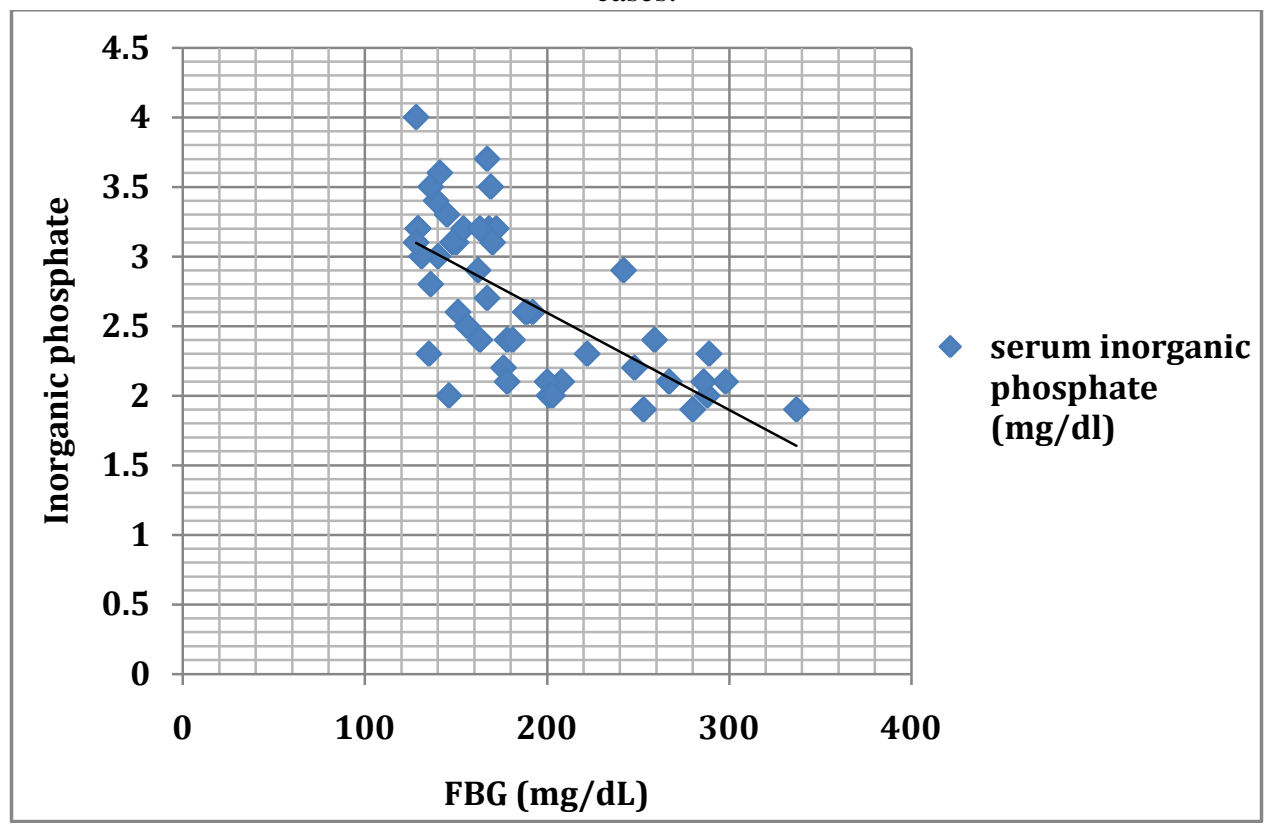

Regression analysis:

In the equation $y=a+b x$

Taking $\mathrm{y}=$ serum inorganic phosphate level and $\mathrm{x}=$ fasting blood glucose

Regression analysis revealed that $\mathrm{a}=3.9899$, And $\mathrm{b}=-0.007$

Now, the equation becomes,

Serum inorganic phosphate level $=3.9899+(-0.007) \times$ fasting blood glucose

Thus, the serum inorganic phosphate level can be calculated from the fasting blood glucose

\section{Discussion:-}

Diabetes mellitus (DM) refers to a group of common metabolic disorders that share the phenotype of hyperglycemia. Several distinct types of DM are caused by a complex interaction of genetics and environmental factors. Depending on the etiology of the DM, factors contributing to hyperglycemia include reduced insulin secretion, decreased glucose utilization, and increased glucose production. The present study "A correlative study of Serum Inorganic Phosphate concentration and fasting blood glucose in type 2 Diabetes Mellitus - A hospital based study", was undertaken in an attempt to understand the role of serum inorganic phosphate in diabetes mellitus as well as to understand the interplay between serum inorganic phosphate level and fasting blood glucose in the progression of type 2 diabetes mellitus.

In the present study it was observed that the mean serum inorganic phosphate level in male with type 2 diabetes was $2.73 \pm 0.58 \mathrm{mg} / \mathrm{dL}$ and those in female cases, $2.6 \pm 0.54 \mathrm{mg} / \mathrm{dL}$. Here, the difference between male and female cases was very minimal and was statistically not significant $(\mathrm{p}>0.05)$.

In control group also, the difference between male and female cases was very minimal and it was statistically not significant $(\mathrm{p}>0.05)$. The above findings indicate the serum inorganic phosphate levels are independent of the gender of the study groups. Haap $\mathrm{M}$ et $\mathrm{al}^{10}$ in 2006 showed that there was a significant association of low serum phosphate concentration with high 2 -h blood glucose levels independent of anthropometric parameters like body fat, age and gender.

In the present study, the mean level of serum inorganic phosphate in diabetic cases was found to be $2.68 \pm 0.56$ $\mathrm{mg} / \mathrm{dL}$. On the contrary, in the control group the mean serum inorganic phosphate level was found to be $3.64 \pm 0.42$ $\mathrm{mg} / \mathrm{dL}$. The serum inorganic phosphate levels in diabetic cases was found to be lower than that in the control group and it was statistically highly significant $(\mathrm{p}<0.01)$. 
The findings of the present study are consistent with findings of Ugwuja EI et al ${ }^{11}$ in 2007. They had examined serum phosphate level along with other parameters in 60 Diabetic patients and compared with 60 apparently healthy, age and sex matched controls. They found that serum phosphate levels are significantly lower in diabetic patients than in controls $(\mathrm{p}<0.05)$. In diabetes mellitus, increased urinary loss due to osmotic diuresis may be the common and most important cause of reduced phosphate, although intracellular shift may also be a factor.

Osmotic diuresis present in hyperglycemic and acidemic states may cause an increased phosphate excretion due to competition between phosphate and glucose in proximal tubular system ${ }^{10}$.

In Diabetes Mellitus, a major disturbance in phosphate handling occurs in the kidney tubules, where the excessive sodium-dependent glucose reabsorption depolarizes the electrochemical sodium gradient. Since inorganic phosphate use the same driving force, but have less binding to sodium than glucose, the inorganic phosphate reabsorption, particularly in poorly regulated patients, becomes impaired. This paradoxical phosphate imbalance may lead to affinity hypoxia and impaired formation of high energy phosphates. The lack of intracellular phosphate complementary to the increased intracellular glucose takes place in the insulin-insensitive cells and tissues, resulting in the possibility of late complications of diabetes mellitus ${ }^{12}$.

The findings of present study are also supported by study of Nagasaka $S$ et al ${ }^{13}$ in 1995 . They showed that NIDDM patients had lower level of serum phosphate at the time of admission, and the values of serum phosphate significantly ( $\mathrm{p} 0.01$ ) increases after hospitalization period, when glycemic control was markedly improved. They also showed the positive correlation between serum phosphate concentrations and renal threshold for phosphorus excretion on admission $(\mathrm{r}=0.86, \mathrm{p}<0.01)$, and between urinary glucose and urinary phosphate on admission $(\mathrm{r}=$ $0.46, \mathrm{p}<0.05)$. These results indicate that hyperglycemia causes excess urinary phosphate excretion in patients with $\mathrm{NIDDM}^{13}$.

In NIDDM (Type $2 \mathrm{DM}$ ), abnormally high blood glucose is linked to non physiologic variations in plasma insulin content throughout a $24-\mathrm{hr}$ period. During hyperglycemic-hyperinsulinemic conditions, high amounts of glucose enter in to muscle and fat tissues which are insulin sensitive. Intra cellular glucose is metabolized by phosphorylation which leads to lower levels of plasma phosphate and consequent negative effects on glucose metabolism in the insulin-insensitive tissues ${ }^{8}$.

Ditzel et $\mathrm{al}^{14}$ studied renal handling of Pi (inorganic phosphate) in 26 conventionally treated diabetic children and in 28 healthy children and found fasting urinary phosphate excretion 3 times higher in the former group despite a significantly lower fasting Pi. The maximal capacity of renal tubular reabsorption of phosphate per liter of filtrate (TmPO4/GFR) was significantly suppressed in the diabetic patients. The increased urinary phosphate excretion correlated positively with both urinary glucose excretion and blood glucose concentration $(P<0.01)$. This finding was unrelated to serum PTH or to plasma growth hormone ${ }^{14}$.

Kalaitzidis $\mathrm{R}$ et $\mathrm{al}^{15}$ in 2005 observed that patients with metabolic syndrome showed significantly lower phosphate and magnesium levels compared with controls. The findings in the present study were consistent with the reports of the above workers.

It is observed from present study that FBS $\geq 200 \mathrm{mg} / \mathrm{dL}$ group had lower phosphate $(2.14 \pm 0.25 \mathrm{mg} / \mathrm{dL})$ than the group which had FBS $<200 \mathrm{mg} / \mathrm{dL}$ and it was statistically highly significant $(\mathrm{p}<0.01)$.

It was also observed in the present study that serum inorganic phosphate levels showed a negative correlation with fasting blood glucose levels, that was statistically significant $(\mathrm{p}<0.01)$. The Pearson correlation coefficient " $\mathrm{r}$ " which was found to be $\mathbf{- 0 . 6 7}$ established the negative correlation between the two parameters.

The findings of present study are almost consistent with findings of Nagasaka $S$ et al ${ }^{13}$ in 1995 . They showed that in NIDDM patients at the time of admission in to hospital, $\mathrm{HbA}_{1 \mathrm{c}}$ was $11.1 \pm 0.3 \%$ and the serum phosphate was 1.12 $\pm 0.03 \mathrm{mmol} / \mathrm{l}$. The values of $\mathrm{HbA}_{1 \mathrm{c}}$ and serum phosphate became $9.3 \pm 0.2 \%$ and $1.21 \pm 0.03 \mathrm{mmol} / \mathrm{l}$ respectively at the time of discharge from the hospital when glycaemic control was markedly improved and the changes in the values were statistically significant $(\mathrm{p}<0.01)$. Thus, they showed that when there was significant reduction of $\mathrm{HbA}_{1 \mathrm{c}}$ $\%$ in NIDDM patients, the serum phosphate level rose significantly. 
Raskin and Pak ${ }^{16}$ studied 21 diabetic patients in whom treatment results ranged from "suboptimal" to "optimal" control and found that, as the mean plasma glucose decreased from $17.1 \mathrm{mmol} / \mathrm{L}$ to $5.2 \mathrm{mmol} / \mathrm{L}$ over 4 to 10days, serum phosphate level rose from 1.12 to $1.26 \mathrm{mmol} / \mathrm{L}(P<0.001)$.

Gertner et $\mathrm{al}^{17}$ studied mineral metabolism in 7 juvenile onset diabetic patients before and after achieving near normal glucose levels by 7 to 14 days treatment with a portable subcutaneous insulin infusion system. They found that as plasma glucose decreased from an average of $221 \mathrm{mg} / \mathrm{dL}$ to $95.9 \mathrm{mg} / \mathrm{dL}$, serum inorganic phosphate rose from 4.09 to $5.01 \mathrm{mg} / \mathrm{dL}(P<0.001)$ due to a $25 \%$ rise in renal tubular threshold for phosphate. No change was noted in immunoreactive parathyroid hormone (PTH) and in 1, 25hydroxy-vitamin D.

Haglin et $\mathrm{al}^{18}$ in 2001 , Park W et a ${ }^{19}$ in 2009 showed the negative correlation between serum phosphate levels and fasting blood sugar levels.

The findings in the present study were supported by the reports of the above workers.

\section{Conclusion:-}

The present study was undertaken to determine the serum inorganic phosphate concentration and fasting blood glucose in newly diagnosed type 2 diabetes mellitus patients and also to determine the correlation of serum inorganic phosphate concentration with fasting blood glucose of the patients.

The study showed that the serum inorganic phosphate concentration was significantly decreased in the diagnosed type 2 diabetes mellitus patients in comparison to healthy individuals. Moreover, there was a significant reduction of serum inorganic phosphate concentration in cases whose glycaemic control was poor, which was reflected by increased fasting blood glucose. There was a statistically significant negative correlation between serum inorganic phosphate concentration and fasting blood glucose in patients of type 2 diabetes mellitus in the present study. Therefore, these findings indicate that there was a definite reduction of serum inorganic phosphate concentration in type 2 diabetes mellitus patients as long as glycaemic control was not achieved and that reduction of serum inorganic phosphate concentration may have a contributing role in the progression of the disease and development of complications of diabetes.

The major issue arises whether to estimate serum inorganic phosphate levels routinely in all type 2 diabetes patients and whether to set a cutoff value of serum inorganic phosphate for good glycaemic control remains to be seen. Further studies with large sample size and longer duration of study with newer methods, which gives a more accurate picture of the actual serum inorganic phosphate and fasting blood glucose status of the body, are required which might shed greater light in this regard.

\section{References:-}

1. Burtis CA, Ashwood ER, Bruns DE. Teitz text book of clinical chemistry and molecular diagnostics. In.: ELSEVIER; 2012. p. 1415.

2. Zimmet P, Alberti KGMM, Shaw J. Global and societal implications of the diabetes epidemic. NATURE. 2001 Dec; 414.

3. Park K. Textbook of preventive and social medicine. In.: BHANOT; 2013. p. 363.

4. Longo DL, Kasper DL, Jameson JL, et al, editors. Harrison s Principle of Internal Medicine. In.: McGraw-Hill; 2012. p. 2969.

5. Frank B. Globalization of Diabetes: The role of diet, lifestyle and genes. Diabetes Care. 2011 June; 34(p 12491257).

6. Mohan V, Shah S, Saboo B. Current glycemic status and Diabetes realated complications among type 2 diabetes patients in India:Data from the A1chieve study. SUPPLEMENT TO JAPI. 2013 JANUARY; 61.

7. Burtis CA, Ashood ER, Bruns DE. Teitz text book of clinical chemistry and molecular diagnostics. In.: ELSEVIER; 2012. p. 1748-1751.

8. Vorum H, Ditzel J. Disturbance of inorganic phosphate metabolism in Diabetes mellitus : its relevance to the pathogenesis of diabetic retinopathy. Journal of Ophthalmology, Hindawi. 2014 March; 2014.

9. Longo DL, Fauci AS, Kasper Dl, et al, editors. Harrisons principles of of Internal Medicine. In.: Mc Graw Hill; 2012. p. 2970. 
10. Haap M, Hellar E, Thamer E, Tschritter O, Stefan N, Fritsche A. Association of serum phosphate levels with glucose tolerance, insulin sensitivity and insulin secrettion in nondiabetic subjects. European journal of clinical nutrition. 2006; 60(734-739).

11. Ugwuja EI, Eze NA. A comparative study of serum electrolytes, total protien, calcium and phosphate among diabetes and HIV/AIDS patients in Abakaliki, Southeastern, Nigeria. The Internet Journal of Laboratory Medicine. 2007; 2(1).

12. Ditzel J, Lervang HH. Disturbances of inorganic phosphate metabolism in diabetes mellitus: temporary therapeutic intervention trial. Diabetes, Metabolic Syndrome and Obesity:Targets and Therapy. 2009; 2(173-179).

13. Nagasaka S, Murakami T, Uchikawa T, Ishikawa SE, Sato T. Effect of glycemic control on calcium and phosphorus handling and parathyroid hormone level in patients with non insulin dependent Diabetes Mellitus. Endocrine Journal. 1995; 42(3,p377-383).

14. Ditzel J, Brochner-Mortensen J, Kawahara R. Dysfunction of tubular phosphate reabsorption related to glomerular filtration and blood glucose control in diabetic children. Diabetologia. 1982; 23(5 p-406-410).

15. Kalaitzidis R, Tsimihodimos V, Bairaktari E, Siamospoulos KC, Elisaf M. Disturbances of phosphate metabolism : another feature of Metabolic Syndrome. American journal of kidney diseases. 2005 May; 45 (5 p851-858).

16. Raskin P, Pak CYC. The effect of chronic insulin therapy on phosphate metabolism in Diabetes Mellitus. Diabetologia. 1981; 21(1(p-50-53)).

17. Gertner JM, Tamborlane WV, Horst RL, Sherwin RS, Felig P, Genel M. Mineral Metabolism in Diabetes Mellitus : Changes accompanying treatment with a Portable Subcutaneous Insulin Infusion System. The Journal of Clinical Endocrinology and Metabolism. 1980 May; 50(5).

18. Haglin L, Lindblad A, Bygren LO. Hypophosphataemia in the metabolic syndrome. Gender differences in body weight and blood glucose. Eur J Clin Nutr. 2001; 55(6 p 493-498).

19. Park W, Kim BS, Lee JE, et al. Serum phosphate levels and the risk of cardiovascular disease and metabolic syndrome; a double edged sword. Diadetes Res Clin Pract. 2009 Jan; 83(1 p 119-125). 